\title{
How to Emerge from the Crisis and from Crisis: Lessons Learned from a European Survey
}

\author{
Philippe Jourdan \\ Professor of Management, IAE Gustave Eiffel / Paris-Est Créteil University, Groupe IRG \\ Place de la porte des Champs, 4 Route de Choisy, 94010 Créteil Cedex, France
}

Tel: 33-1-4178-4735 E-mail: philippe.jourdan5@gmail.com

Olivier Meier

Ass. Professor and Qualified Research Supervisor, University of Paris Est - IRG

Campus universitaire de Sénart, 77127 Lieusaint, France

Tel: 33-1-6413-4481Ｅ-mail: olmeier@yahoo.fr

Jean Claude Pacitto

Université de Paris Est, PhD, Research Director - IRG, 77127 Lieusaint, France

Tel: 33-1-6413-4481 E-mail: pacitto@u-pec.fr

\author{
Richard Soparnot \\ Professor of Strategy and Management, Loire Valley University/CRESCEM/ESCEM - VALLOREM EA 6296 \\ Groupe ESCEM, 1 Rue Léo Delibes, BP 0535, 37205 Tours Cedex 3, France \\ Tel: 33-2-477-7168Ｅ-mail: rsoparnot@escem.fr
}

Received: September 9, 2011

Accepted: April 16, $2012 \quad$ Published: June 1, 2012

doi:10.5539/ibr.v5n6p105

URL: http://dx.doi.org/10.5539/ibr.v5n6p105

\begin{abstract}
The authors would like to sincerely thank Mercuri Urval, which funded and spearheaded this European study. The talents of the firm's managers were invaluable to compiling a robust study, filled with lessons. This fascinating collaborative work demonstrates how much management culture is enriched by juxtaposing academic knowledge and experience on the ground.
\end{abstract}

Keywords: Crisis management, International management, Innovation

\section{Introduction}

Situations of economic or financial crisis are not exceptional phenomena in the history of a country or company. Observers have learned to make connections between several factors characterizing a crisis (Commission of the European Commities, 2008; Cole \& Ohanian, 2009). Seizure, in the mechanical meaning of the term, constitutes the first factor. This concerns situations where certain nuts and bolts in the economy cease to function and do not appear capable of restarting. The second factor concerns an a posteriori observation of far-reaching and long-term malfunctions. Thirdly, a crisis exists whenever it may be observed that market segments are unable to correct themselves, or that such correction time is excessively long and the correction itself far from perfect. Readily localisable and identifiable market failures are, in fact, what constitute the fourth characteristic of a crisis. Finally, there is a crisis whenever the solution to a largely deteriorated situation involves structural changes (calling the system into question) and when government intervention is necessary.

When we analyse these various factors, we are compelled to observe that the situation we have been witnessing since summer 2007 is indeed that of a major crisis (Elmendorf, 2009). Aside from its intrinsic depth, this crisis is characterised by both contagion and contamination phenomena. Contagion occurs when difficulties in a country's financial sector spread to the same sector in one or more other countries. We may also speak of contagion when the 
difficulties in one financial sector result in weaknesses in other financial sectors (we might just as easily speak of systemic risk). Contamination, on the other hand, occurs when the financial crisis spreads from the financial sector to the real sector. We are well aware that we are currently in the presence of both contagion and contamination. Thus, it is not simply the international financial system that is affected, but also all corporations, in their strategies, in their operations and in all aspects of their management.

Although the path has been bumpy at times, especially with the bursting of the bubble in the electronic sector in 2000, the last 2 decades have been years of sustained growth in industrialized countries and of spectacular growth in a number of emerging countries. The current crisis marks the end of this 20 -year cycle. The genuine euphoria that had gripped some economies (the American, British and Spanish economies, for example) is now giving way to a far-reaching crisis. Very few studies have directly focused on competitive strategies in industries in crisis. Management studies define the notion of crisis as a situation that threatens the functioning, objectives and values of an organisation (Hermann, 1963) and that leads to the formulation of new managerial practices. The exceptional nature of the crisis, in effect, implies strong uncertainty (Milburn, Schuler \& Watman, 1983) and raises the issue of a need to reconfigure resources and the role of the manager, due to the necessarily shortened time between decision-making and action. From this standpoint, any crisis will endanger the operating framework of a given company and put its reputation and that of its manager on the line (Libaert, 2001); it will imply choices, changes in attitude, decisive actions and, generally, the development of specific capabilities and procedures in order to eliminate the insecurity. It may also generate stronger emotional pressures, rendering communication and relationships with others more sensitive.

Crisis phenomena firstly manifest as a lack of visibility with anxiogenic consequences for economic players (Crossan, Cunha, Vera \& Cunha, 2005). The effective complexity of the crisis is a factor that can lead to anxiety and misunderstanding; hence, crises sometimes lead managers to deliver a simplified interpretation of their complexity to enable their teams to identify and take on board key problems without spreading themselves too thinly. The complexity of the situation, the uncertainty, the fear of the unknown and the lack of visibility trigger a sort of survival reflex in managers, especially those in large organisations. Managers often have their own ideas on how to deal with the crisis, but dare not suggest, or even implement them (Adrot \& Garreau, 2010). It is important to leave room for "unconventional" ideas. We can cite the example of a large company whose managers had rejected a project involving a unique co-operative solution, with a highly transparent operating method. However, they subsequently invited the project's creator to a management board meeting for further discussions about the project and today, amid the current crisis, the project is under closer scrutiny and may indeed be implemented. So how do you instil confidence in your employees when, as a manager, you lack sufficient visibility to see clearly into the future? This is the fourth key to success in crisis leadership: the ability to be consistent, both in decision-making and in the attitudes adopted in a crisis context - intrinsic consistency in what you do, say and decide. Such consistency engenders confidence, and gives employees the feeling that their manager has a map to help him navigate and stay on course in a turbulent and uncertain climate. Displaying consistency means rendering work processes visible, clearly announcing the main milestones on the horizon since the future is uncertain, taking an active interest in field feedback and taking the time to truly listen to your employees (Besson \& Lavorata, 2010).

Finally, in periods where uncertainty reigns, the difference between success and failure often lies in the company's ability to deviate from the more cautious cost rationalisation approach in order to take entrepreneurial measures, develop market share and improve results (Duquesnois, Le Roy \& Gurau, 2010). In a recovery context, the situation facing companies who have adopted the first approach, i.e. the wait-and-see policy, is at best identical to their initial status. Conversely, those who opt for the second, i.e. the innovative approach, gain a competitive edge and post positive long-term results. The growing economic difficulties and financial constraints mean that many companies are prompted to rethink their development model and resource systems, by seeking out as yet unavailable skills via the search for new combination modes (Naidoo, 2010; Despahandé \& Farley, 2004).

But how was perceived the recent crisis?

\section{The Study}

The Panel On The Web Institute and the consulting firm Mercuri Urval recently conducted a survey of 844 businesses in 8 countries (Austria, Belgium, Denmark, France, Germany, Italy, the Netherlands and Switzerland), which yielded some interesting results on perceptions of the effects of the crisis and the measures to be taken in order to emerge from it. The objective of the survey was to build upon the recent crisis in order to identify the key factors for success likely to ensure sustained growth for companies, by interviewing a group of senior managers, including a high proportion of executive officers $(57 \%)$. 
The questionnaire comprised 37 questions (both quantitative and qualitative) on the perception of the crisis and the assessment of the key factors for a return to sustainable growth. The 46 factors were therefore organized into 4 main factors: financial management (11), specific skills (11), internal management (13), market / customer orientation (11). The CAPI face-to-face interviews were conducted by senior consultants from Mercuri Urval, a human resources consultant firm which funded and spearheaded this European study. Each one lasted around $1 \mathrm{~h} 30$ minutes. Different sectors of activities were chosen from industry to services, mixing small, average and big sized-firms (with no specific quotas albeit). The field was conducted in October and November 2009.

The study was conducted face-to-face while the effects of the crisis were still being sharply felt (table 1), and revealed surprising results on more than one level (see for example in table 2 the hierarchy of the indicators used by Top Management to assess the health of their company and the surprisingly low importance of the stock price and the health of the sector). In fact, even though the crisis will still have an impact on businesses in 2010, it cannot be said that pessimism is the dominant sentiment to emerge from the results of the survey. Fundamentally, to managers in Europe, the crisis appears to have been the best time to think about new solutions and particularly, to carefully consider the competitive levers for their business and try to answer the following question: in such a hard-hit environment, what will return my company towards growth? A reading of the economic news would easily lead one to believe that companies are singularly obsessed with cutting costs. However, this is far from the truth, and in fact, for many companies, priorities include finding ways to enhance the value of human capital, which is seen as one of the keys to breathing new life into companies. In this regard, the crisis was revealing. In the face of all kinds of constraints, it is important to enhance value across the board, including in quality of services, enhancing core competencies, quality of recruitment, training, ability to innovate, etc. This approach, which is akin to making a $360^{\circ}$ turn in terms of management, is generally being embraced by all the industrialized countries in Europe, regardless of whether they are located in the North, South, East or West.

Insert Table 1 Here

Insert Table 2 Here

Although the valuation strategy does not preclude a strategy to reduce the costs, its increasing popularity reveals a new mindset and desire to enhance internal competencies with the objective of identifying new ways of doing things. From this perspective, it is apparent that companies are no longer simply trying to differentiate their goods and services, but are also trying to do things differently, that is to make a greater commitment to strategies involving change. The crisis remains quite a constraint, but also presents a wonderful opportunity, a unique time to create value and to dare to think of things that were unthinkable during normal times. In reality, this awareness was also prompted by thoughts about the future of European companies: crisis or no crisis, the globalization of economies goes hand in hand with delocalization of businesses, a phenomenon which led all European companies to "take their new destiny into their own hands," to quote one of the managers interviewed.

\section{The Crisis as an Opportunity}

\subsection{Exploring New Approaches}

Although $73 \%$ of the companies surveyed believed they were affected by the crisis, this result must be tempered by two other results. First, in 2010, 61\% believe that their situation will improve and second, and perhaps more importantly, $77 \%$ believe that the crisis provided them with a wonderful opportunity, an opportunity, most notably, to implement new management methods (see table 3). The crisis is therefore frequently viewed as the best time to experiment, a unique time to test new ways of doing things. The fact that changes were made during and as a result of the crisis is therefore not a myth, it is a reality. From this point of view, the crisis is a time which made it possible to experiment, a time when resistance faded in the face of the urgent need to return to generating growth. Although internal tensions were exacerbated by corporate plans, the crisis also presented an opportunity to (re)mobilize all personnel, a vision, however, that was more entrenched in companies in Northern Europe (Germany, Belgium and Denmark) than in those in central Europe (France) and Southern Europe (Italy).

\section{Insert Table 3 Here}

The crisis was also the time when projects that had previously been considered (or left dormant for a very long time) materialized into action plans. The results of the survey also revealed a large degree of consistency between the perception of the crisis and the factors likely to enable companies to confront it, and the action plans that were implemented. The indicated priorities were reflected in the operational strategy; they were not simply used as sound effects for internal use. The desire to win over new customers, improve service, increase the level of motivation among employees as well as profitability became the focus of concrete actions. 
The crisis is therefore the time to reconsider and as we will see, this process involves questioning existing practices but, more importantly, provides an opportunity to explore new approaches deemed to be too risky during periods of growth. In future, effective implementation of such approaches can be authorized by offering managers new "target areas." A reading of the numbers reveals that although the crisis favors this time of collective reflection, it certainly provides one of those rare moments where there is a risk of completely changing routine practices, all too often inspired by a "benchmark" or simply "cutting and pasting" the actions of others. In a way, it is also the best time to adjust to and even make changes proactively. By adjusting to changing economic conditions, the goal is indeed to adapt to a new economic cycle: that of hyper-competition (globalization of economies, competition from developing countries) and hyper-risk (emergence of new financial, economic, environmental, corporate and political risks, etc.). It is also a time when weaknesses or problems for which solutions had been postponed because they were not considered to be priorities are revealed and reconsidered and perceived as impediments to growth.

\subsection{Improving Existing Resources}

The crisis is also the best time to redefine priorities and from this point of view, the findings of the survey are quite interesting. The top priority is to reinforce human capital as a preamble to the dual concerns of improving the quality of service (a key success factor in a post-industrial economy) and listening to customers (a prerequisite for confidence and consumer spending to return). Withstanding the crisis and emerging from it faster than competitors requires placing greater value on human capital, a value which is deemed to be the only one likely to create conditions for success in the medium and long term. It is easy to see that at this level, management is no longer a matter of applying techniques better than others but requires often complex management of competencies, an area which also requires experimenting with new ways of doing things (see table 4).

Faced with budget constraints that have become even more restrictive, businesses have become aware that searching for reservoirs of productivity, knowledge and lastly innovation should start within the business itself. The crisis has had an undeniably introspective effect. It is a time when businesses embark on a journey of self-discovery by focusing attention on existing resources and the multiple ways to develop them even further. It is also a time when the dynamic and progressive aspects of the human factor are being acknowledged.

With respect to the two other priorities, we realize that for businesses, it is no longer a matter of simply repeating the claim that the customer is king, but to create the conditions for such a claim effective. Quality of service must be "real" and not simply serve as a company slogan; a majority of businesses share the opinion that they need to improve their ability to listen to customers. This demonstrates that companies have become aware that relationships with customers are not always optimal and that everything is not always done to listen to customers. By complicating maintenance of the business/customer relationship, the crisis is forcing companies to extensively reconsider this relationship and act, from a business point of view, to attract new customers on the one hand and foster greater loyalty among existing customers on the other. This is achieved through a service strategy that is clearly identified as a priority. In a way, the crisis is therefore the moment of truth, a time to assess certain measures and strike a balance between objectives which are often posted definitively and their actual effectiveness. Considered all too often to be a matter of techniques or managerial trends, the customer relationship is now being assigned a new objective: being effective. It is important to remember that this effectiveness is increasingly being achieved through policies based on personalization in areas which are often dominated by an impersonal relationship falsely gilded with so-called personalization.

From this point of view and this is where the survey provided an optimistic vision of the post-crisis period, the crisis will no longer simply trigger introspective reflexes, but will prompt real strategic diagnoses where weaknesses are no longer underestimated but seen as major obstacles to growth and the most certain path to failure.

Insert Table 4 Here

\section{How to Return to Generating Growth}

\subsection{Is the Market/Customer Focus an Initial Reflex?}

With respect to the key success factors likely to ensure growth, the survey revealed that although the market-focused approach is still preferred (76\%), core competencies obtained the second highest score $(61 \%)$ far ahead of internal management (43\%) and finance and management (32\%). Although companies continue to prioritize the marketing approach, they no longer ignore the extensive reserves of their competitive abilities. The strategic and marketing aspects are no longer separated. With respect to the market-focused approach, business priorities are clearly focused on obtaining new customers (71\%); this approach therefore significantly outpaces fostering loyalty among customers $(55 \%)$, often promoted by academic literature, and customer service $(45 \%)$ as the immediate and initial reaction to a decline in activity and business revenue. As we will explain in further detail, the crisis has accelerated a return to basics. Fewer efforts are being made to establish an international presence, expand into new markets and improve 
short-term availability, and instead, more efforts are being spent on restoring profitability and a sufficient level of activity, achieved by strengthening relations with its best customers. However, as indicated above, this strengthening of customer relationships is also clearly perceived as the main priority for companies in the future (see table 5). At this level, the crisis certainly revealed weaknesses.

The crisis affected the customer portfolio of most companies and this is exactly what needs to be restored. We should therefore not be surprised that for companies in Belgium and The Netherlands, the scores for identifying new customer expectations were very high. Companies are no longer content to implement adaptive strategies; they also want to anticipate market trends. This approach is more popular in a block of small countries in the North (Belgium, The Netherlands, etc.) than it is in all other countries, undoubtedly because company managers in these countries are aware of the limitations of their domestic markets.

Insert Table 5 Here

\subsection{Is Innovation a Crisis Killer?}

Quite logically, with respect to specific anti-crisis skills, companies prefer innovation (63\%) over quality of service (54\%) (see table 6). The results of the survey not only reveal the importance of innovation, but also reveal the fact that companies want to accelerate the frequency of this innovation in a concrete manner. Indeed, it is through innovation (fortunately) that companies hope to attract new customers and meet new expectations. On this level, the crisis has appeared to amplify awareness that it is necessary to enter an era of "change" and not just "differentiation" in terms of innovations. Indeed, in order to emerge from the crisis, the ability to simply be different does not appear to be the preferred approach. Innovation must serve as a means to break with tradition and redefine the value of products and services. This explains why human and intellectual capital is also being valued. Change strategies, more than any other strategy, require mobilization of skills and new combinations of skill sets. Companies not only focus on what they own and what they know how to do, but also move beyond that point to think of new ways of doing things. Innovation is clearly perceived as being the result of a complex disruptive process and no longer as the result of strict obedience to an internal process directed solely by the R\&D function.

This helps clarify why innovation ranks second for strategies in existing action plans. Innovation is not an order, it is the result of multiple actions implemented within the company; it can be encouraged but it can never be determined. In the ranking for the key success factors, we realized that there is a certain logic to the choices being made by companies. Winning over new customers comes first, ahead of innovation, which in a way is the means of achieving these conquests, and ahead of profitability, a consequence of the first two key success factors. The hierarchy of core competencies which must be mastered is quite logical: strengthening the ability to innovate in order to win new customers, improving quality of services to foster greater customer loyalty and then investing in human and intellectual capital, now considered to be a greater priority than just technological and material capital within the context of a post-industrial economy. Of course, some disparities remain among countries. The Italian economy, which has a substantial sub-contracting economy, is having to deal head on with competition from developing countries in terms of costs and expects to maintain its investments in order to improve its productivity; France is placing further emphasis on the quality of service, while countries in the North - Belgium, The Netherlands and especially Denmark - are trying to enhance organic growth.

Insert Table 6 Here

\subsection{Is Taking Action Based on Employee Motivation a Profitable Investment?}

The effect of the crisis also had an impact on the priorities indicated for internal management (see table 7). A major concern for businesses is of course the motivation of employees (60\%), which is a higher priority than management of skills and profiles (48\%). In this case, the short term is given priority and indirectly, we have a good indication of a corporate climate which has undoubtedly been affected by the crisis. Of course, a number of differences can be noted from country to country: Italy, a country with a strong tradition of unionism is more concerned with the deterioration of the corporate climate, which explains its focus on motivating employees and middle management and catching up with requisite salary increases; countries in the North - Denmark, Belgium but especially The Netherlands - are inclined to invest in new structures of work organization (collaboration, network, project by project, etc.) in order to offer other perspectives to employees and managers. However, in a European context where the recent crisis has served as a catalyst for previous frustrations resulting from the stagnation of purchasing power since the move to the euro (with a marked impact in some countries, especially in France, due to the gap between price increases and employee income), it is therefore not surprising that senior managers are concerned about the decline in the motivation of middle management (which ranks 3rd in terms of priorities for action). Most of the survey respondents held senior management positions, which undoubtedly explains the relative discretion of their own level of motivation. However, 
many were of the opinion that the crisis had had a very negative effect on the motivation of middle management and even more so on employees and technicians at the lower end of the scale.

\section{Insert Table 7 Here}

For all businesses, regardless of the sector concerned, one key to emerging from the crisis lies in management's ability to ensure that employees remain motivated and that the crisis does not affect the internal cohesion of companies. At least as much as classic economic-related effects (decline in business revenue and profitability), today's fears concern the internal breakdown of a business at the very point when it is counting on its human assets to emerge from the crisis and discover new ways to foster growth. When asked questions about the actions that had been planned to deal with this area of concern, we note that there is no dissonance between what was said and actions to be taken. Indeed, actions have been planned to improve the level of motivation of employees and they are being prioritized. However, there is marked homogeneity in the envisaged priorities: in Denmark and Belgium, emphasis is being placed on new forms of organizing work such as collaborative management, organizing networks or management on a project by project basis. In France, priorities concern management of profiles and skills, motivation of employees and amending work hours to offer greater flexibility. In Italy, improved management of internal promotion and adjustments to the salary schedule are planned in order to prioritize improvement in the corporate climate. Although the final objective is always the same (improve employee motivation adversely affected by crisis management solutions, corporate plans, cost cuts, salary freezes, etc.), each country defines its priorities based on the social context, economic environment and professional culture specific to that country.

More generally speaking and beyond the crisis, we therefore note that the issue of employee motivation has recently returned with a vengeance. Perhaps, we have for too long taken this for granted, believing that motivation resulted from a few well-known formulas. Although the results of the survey must be interpreted with care (due to the effects of the crisis), they nevertheless reveal that employee motivation is an issue which concerns all levels of the business, because, as admitted by the managers themselves, it affects the most basic of elements: involvement in the work. The companies surveyed ranked the need to motivate higher than the need for skills because they believe that greater motivation is a prerequisite for developing skills, which are often the end result. From now on, much is expected from motivation, because aside from greater involvement, companies also want employees to take the initiative and, regardless of the position held, become resources and allow the company to achieve its objectives, most notably in terms of innovation.

\section{Return to Basics}

\subsection{The More Things Change}

The crisis has been very revealing. By prompting introspection, it has improved diagnosis of the effectiveness of the strategies implemented up to that point and allowed questions to be raised regarding the opportunity to experiment with new approaches or simply return to basics, most notably through customer relationships and effectively valuing human resources. The key success factors indicated highlighted a clear perception of the drivers to be competitive as well as a clear perception of future challenges and actions to be taken in order to deal with them. From this point of view, innovation has a dual objective: to help businesses emerge from the crisis and allow companies to renew their strategic advantages. Due to its role as a catalyst, the hope is also that innovation will influence the motivation of employees through the implementation of so-called pilot structures, where the goal is to obtain greater interaction between the various stakeholders of the company. It is important to point out that this new vision of managing motivation through new organizational choices and new work methods is currently more popular in the "smaller" countries in Northern Europe than it is in the other large countries (France, Germany, Italy, etc.). Belgium, The Netherlands and Denmark have given strong indications that they are committed to implementing action plans in these areas, while France, Germany and Italy are starting to study these issues. Does this reflect a different hierarchy in corporate concerns? Does it reflect a greater ability to react and adjust in "smaller" countries in the North? Does it reflect resistance to changes in economies used to "rounds" of corporate negotiations?

Whatever the reason, some economies - particularly Italy, but also France, Germany and Switzerland - appear to be showing greater resistance than others vis-à-vis new managerial practices, which they deem to be important but have yet to establish any real priority of action for them to date (e.g., management within the context of a network, delegation, project management, collaborative management, etc.). Whether it is a reaction to the current trend or a focus on the essential, companies are opting for a certain degree of classicism in terms of management and would like first and foremost to improve the quality of service.

With respect to the quality process, the desire in this area is also to return to basics, customer service, quality of service, listening to customers. The bet is that by making these objectives more effective, it will not only be possible to win over new customers but to enhance their loyalty. In all sectors, improving processes is currently all the rage. It is no 
longer a matter of doing something new just for the sake of it, but of questioning the actual effectiveness of practices until they are implemented, and then doing everything possible to optimize these practices. The crisis alone did not create new assessment mechanisms; it simply ensured that they were fully activated. Assessment cannot be separated from the cost-cutting process because it is by optimizing recourse to classic, tried and true techniques that businesses are also trying to obtain savings in order to return to more acceptable levels of profitability as soon as possible. This is the first step, the one that was immediately implemented by almost all countries as of the first few months of the crisis, in order to deal with a decline in business revenue and results. The initial measures focused on reducing investments, limiting expenses, reducing salary costs, risk management (financial, customer, etc.), as well as "classical" measures, which, in some cases, amplified the crisis by having an adverse impact on sub-contractors, suppliers, industrial/commercial partners, etc. (see table 8). Managers in different European countries have become aware of this - and this will now affect long-term actions: encourage innovation on an ongoing basis, sustain innovation, create a value chain involving all stakeholders in the business (customers, suppliers, sub-contractors, employees, managers, investors, shareholders, etc.).

\section{Insert Table 8 Here}

One reassuring fact is that this initial return to basics does not preclude new approaches as it is precisely at this time that people are thinking of new ways of doing things, particularly in terms of optimizing customer relationships. From the same point of view, in order to motivate employees, many companies are betting on management on a project by project basis and are looking for new, perhaps more collective approaches to further involve personnel. This demonstrates how much the crisis has affected the usual methods which businesses use to manage and motivate. It is the individualistic idea of motivation which is also being reconsidered. Although it produces good results during periods of growth, its limitations are easy to see when incentives offered by the business decline. It is the entire balance of the incentive/contribution pairing, which has been so well illustrated by Barnard, which is now being reconsidered.

\subsection{Emphasizing Action}

The businesses that participated in this survey reacted by implementing action plans and ensuring that the stated priorities were operational. Particular attention is being focused on acquiring new customers and it is at this level that businesses are focusing their operational strategies. The priority is therefore to increase business revenue and, at the same time, try to restore profitability. It can be noted that these plans and the market-focused approach have largely been finalized and are currently being implemented. We have moved from the reflection/study phase to the action phase. All action plans concerning key factors of success relating to the market-focused approach have been finalized, which is not the case for those concerning basic skills or, for example, action plans concerning human and intellectual capital which are far from being finalized (see table 9). This demonstrates that the action in this area is complex and cannot simply be reduced to applying proven techniques. Businesses know that they need to act but do not always know what to do. This is further emphasized when we examine action plans for internal management. The action plans are far from being finalized and close to $43 \%$ of businesses have not envisaged an action plan to deal with the issue of motivation, even though it is considered to be a priority. Businesses have diagnosed the problem but appear to be unable to treat the problem (see table10).

\section{Insert Table 9 Here}

Insert Table 10 Here

These results are interesting on more than one level. First, they show that motivation remains an area where operational strategies are difficult to implement. Businesses are definitely showing signs of confusion. This should mean calling upon services associated with management of human resources: what tools should be put in place in order to deal with a lack of motivation? Second, they reveal that when it is a matter of addressing operational issues, businesses are always more comfortable with quantifiable elements or elements that can always be measured. Human assets are certainly perceived as being vectors of growth but it is very difficult to appreciate the actual dynamic involved, particularly in a period of crisis when the usual markers for human resource management seemed to be obscured. Consequently, action plans relating to the area of finance have advanced much further, especially those concerning profitability, cash flow and the financial health of customers.

At this point, we must therefore distinguish between areas where companies can take action and where they are doing so in compliance with the stated priorities, and areas where they would like to act but have had their momentum curbed by the sheer complexity of managing human resources and the difficulty of finding good ways to resolve issues considered to be crucial to the future of the business. Perhaps, at this level, there is a fear of experimenting with management styles for fear of destabilizing the business even further and because there is so little information on these management styles. We can also take the position that treating problems associated with the motivation and 
strengthening of human capital does not fall within the scope of an operational strategy but should be the focus of true strategic reflection, perhaps in the longer term.

The crisis has forced businesses to ask questions; final answers will be obtained at a later date because they require the mobilization of information that businesses do not always have on hand when classic and routine management of human resources faces limitations. Nevertheless, specifically with respect to human resources, we cannot help but notice the quick action taken by businesses in Europe. These plans were developed and implemented in just a few months and in a particularly difficult environment both externally and internally. We can also say that there is no proof that the old plans which were reactivated continue to be relevant; the crisis presented an opportunity to experiment with solutions that had been affected by the circumstances.

\section{References}

Adrot, A., \& Garreau, L. (2010). Interagir pour improviser en temps de crise. Revue Française de Gestion, 203, 120-131.

Besson, M., \& Lavoratta, L. (2010). Impact de la crise économique sur le management commercial. Management et Avenir, 31, 304-320. http://dx.doi.org/10.3917/mav.031.0304

Bleeke, J. (1991). Quatre stratégies pour affronter l'Europe ouverte. Harvard L'Expansion, 99-108.

Cole, H., \& Ohanian, L. E. (2009). How Government prolonged the Depression. Wall Street Journal, February.

Commission of the European Commities. (2008). A European Economic Recovery Plan. Brussels: EC.

Crossan, M. M., Cunha, M. P. E., Vera, D., \& Cunha, J. (2005). Time and Organizational Improvisation. Academy of Management Review, 30(1), 129-145. http://dx.doi.org/10.5465/AMR.2005.15281441

Dawes, S. S., Cresswell, A. M., \& Cahan, B. B. (2004). Learning from crisis - Lessons in human and information infrastructure from the World Trade Center response. Social Science Computer Review, 22(1), 52-66. http://dx.doi.org/10.1177/0894439303259887

Delmas, M., Russo, M. V., \& Montes-Sancho, M. J. (2007). Deregulation and environmental differentiation in the electric utility industry. Strategic Management Journal, 28(2), février, 189-209. http://dx.doi.org/10.1002/smj.578

Despahandé, R., \& Farley, J. U. (2004). Market orientation, innovativeness and organizational culture: thai firms adapt to the Asian economic crisis. Asian Journal of Marketing, January, 5-19.

Duquesnois, F., Le Roy, F., \& Gurau, C. (2010). Stratégies concurrentielles dans une industrie en crise. Revue Française de Gestion. Paris, 36(203), 41-56.

Elmendorf, D. (2009). The state of the Economy and issues in developing an effective policy response. Statement of the Director of the Congressional Budget Office before the Committee of the Budget, 29 January, US House of Representatives.

Feldman, M. S., \& Pentland, B. T. (2003). Reconceptualizing Organizational Routines as a Source of Flexibility and Change. Administrative Science Quarterly, 48(1), 94-118. http://dx.doi.org/10.2307/3556620

Hall, W. K. (1981). Survivre dans un environnement plus rude. Harvard L'Expansion, été, 56-68.

Hermann, C. F. (1963). Some Consequences of Crisis Which Limit the Viability of Organizations. Administrative Science Quarterly, 8(1), 61-82. http://dx.doi.org/10.2307/2390887

Lagadec, P. (1996). Cellules de Crise, Les Conditions d'une Conduite Efficace. Les Editions d'Organisation, Paris.

Lagadec, P. (2000). Ruptures Créatrices. Les Editions d'Organisation, Paris.

Libaert, Th. (2001). La Communication de Crise. Les Topos. Dunod, Paris.

Milburn, T. W., Schuler, R. S., \& Watman, K. H. (1983a). Organizational Crisis. Part I: Definition and Conceptualization. Human Relations, 36(12), 1141-1160. http://dx.doi.org/10.1177/001872678303601205

Milburn, T. W., Schuler, R. S., \& Watman, K. H. (1983b). Organizational Crisis. Part II: Strategies and Responses. Human Relations, 36(12), 1161-1171. http://dx.doi.org/10.1177/001872678303601206

Miller, D., \& Dess, G. (1993). Assessing Porter's (1980) Model in Terms of its Generalizability, Accuracy and Simplicity. Journal of Management Studies, 30(4), 553-585. http://dx.doi.org/10.1111/j.1467-6486.1993.tb00316.x

Naidoo, V. (2010). Firm Survival through a crisis. Industrial Marketing Management, 39, 1311-1320. http://dx.doi.org/10.1016/j.indmarman.2010.02.005 
Table 1. Impact of the economic slowdown on companies' businesses

\begin{tabular}{|c|c|c|c|c|c|c|}
\hline \multicolumn{7}{|c|}{ How would you say your company's situation has been affected so far by the current economic change? Would you say it has been... } \\
\hline & $\begin{array}{c}\text { Very much } \\
\text { affected }\end{array}$ & $\begin{array}{l}\text { Rather } \\
\text { affected }\end{array}$ & $\begin{array}{c}\text { Very much + rather } \\
\text { affected }\end{array}$ & $\begin{array}{c}\text { Rather } \\
\text { unaffected }\end{array}$ & $\begin{array}{l}\text { Completely } \\
\text { unaffected }\end{array}$ & $\begin{array}{c}\text { Rather + completely } \\
\text { unaffected }\end{array}$ \\
\hline Austria & $32 \%$ & $37 \%$ & $69 \%$ & $31 \%$ & $0 \%$ & $31 \%$ \\
\hline Belgium & $42 \%$ & $31 \%$ & $73 \%$ & $21 \%$ & $6 \%$ & $27 \%$ \\
\hline Denmark & $42 \%$ & $36 \%$ & $79 \%$ & $20 \%$ & $1 \%$ & $21 \%$ \\
\hline France & $32 \%$ & $26 \%$ & $58 \%$ & $41 \%$ & $1 \%$ & $42 \%$ \\
\hline Germany & $29 \%$ & $43 \%$ & $72 \%$ & $26 \%$ & $2 \%$ & $28 \%$ \\
\hline Holland & $35 \%$ & $41 \%$ & $76 \%$ & $21 \%$ & $3 \%$ & $24 \%$ \\
\hline Italy & $57 \%$ & $36 \%$ & $93 \%$ & $7 \%$ & $0 \%$ & $7 \%$ \\
\hline Switzerland & $26 \%$ & $33 \%$ & $59 \%$ & $38 \%$ & $3 \%$ & $41 \%$ \\
\hline
\end{tabular}

Table 2. Health economic indicators used by Top Management to assess the impact of the economic slowdown on the business of their own company

\begin{tabular}{|c|c|c|c|c|c|c|c|c|}
\hline \multicolumn{9}{|c|}{ Which health indicators lead you to believe that your business is affected or not by the economic change? } \\
\hline & Austria & Belgium & Denmark & France & Germany & Holland & Italy & Switzerland \\
\hline Sales & $89 \%$ & $90 \%$ & $95 \%$ & $93 \%$ & $89 \%$ & $87 \%$ & $91 \%$ & $89 \%$ \\
\hline Sales (volumes) & $84 \%$ & $73 \%$ & $89 \%$ & $82 \%$ & $86 \%$ & $77 \%$ & $86 \%$ & $85 \%$ \\
\hline Sales (margin) & $53 \%$ & $59 \%$ & $48 \%$ & $49 \%$ & $39 \%$ & $55 \%$ & $50 \%$ & $48 \%$ \\
\hline Financial results & $89 \%$ & $79 \%$ & $67 \%$ & $84 \%$ & $77 \%$ & $77 \%$ & $73 \%$ & $76 \%$ \\
\hline Operational result & $79 \%$ & $66 \%$ & $47 \%$ & $65 \%$ & $69 \%$ & $62 \%$ & $50 \%$ & $71 \%$ \\
\hline Cash reserves & $53 \%$ & $37 \%$ & $26 \%$ & $41 \%$ & $35 \%$ & $43 \%$ & $38 \%$ & $30 \%$ \\
\hline Human ressources & $53 \%$ & $52 \%$ & $41 \%$ & $50 \%$ & $47 \%$ & $61 \%$ & $46 \%$ & $53 \%$ \\
\hline Layoffs & $47 \%$ & $45 \%$ & $33 \%$ & $41 \%$ & $41 \%$ & $52 \%$ & $38 \%$ & $47 \%$ \\
\hline Frost of salaries & $21 \%$ & $21 \%$ & $7 \%$ & $19 \%$ & $11 \%$ & $13 \%$ & $13 \%$ & $12 \%$ \\
\hline Budget \& costs & $53 \%$ & $49 \%$ & $38 \%$ & $44 \%$ & $57 \%$ & $70 \%$ & $55 \%$ & $49 \%$ \\
\hline Operational budget & $21 \%$ & $18 \%$ & $14 \%$ & $13 \%$ & $18 \%$ & $42 \%$ & $14 \%$ & $20 \%$ \\
\hline Investments & $42 \%$ & $39 \%$ & $27 \%$ & $34 \%$ & $42 \%$ & $45 \%$ & $36 \%$ & $29 \%$ \\
\hline Environment & $11 \%$ & $14 \%$ & $9 \%$ & $22 \%$ & $11 \%$ & $12 \%$ & $14 \%$ & $15 \%$ \\
\hline Stock price & $0 \%$ & $10 \%$ & $5 \%$ & $7 \%$ & $10 \%$ & $4 \%$ & $11 \%$ & $6 \%$ \\
\hline Benchmark & $11 \%$ & $4 \%$ & $5 \%$ & $15 \%$ & $3 \%$ & $8 \%$ & $4 \%$ & $9 \%$ \\
\hline
\end{tabular}

Table 3. The economic slowdown: an opportunity to reconsider the management practices

\begin{tabular}{|c|c|c|c|c|}
\hline \multicolumn{5}{|c|}{ Which of these two statements best describe your opinion as of today? } \\
\hline & \multicolumn{2}{|c|}{$\begin{array}{l}\text { The economic slowdown is a wonderful opportunity } \\
\text { to think about and to deploy new management } \\
\text { practices to reach a sustainable growth }\end{array}$} & \multicolumn{2}{|c|}{$\begin{array}{l}\text { The economic slowdown is similar to all the others. After a } \\
\text { while, people will realize that nothing has changed in the } \\
\text { management practices to reach a sustainable growth }\end{array}$} \\
\hline Total Europe & $77 \%$ & Rank & $23 \%$ & Rank \\
\hline Austria & $68 \%$ & 7 & $32 \%$ & 7 \\
\hline Belgium & $76 \%$ & 5 & $24 \%$ & 5 \\
\hline Denmark & $87 \%$ & 1 & $13 \%$ & 1 \\
\hline France & $81 \%$ & 3 & $19 \%$ & 3 \\
\hline Germany & $71 \%$ & 6 & $29 \%$ & 6 \\
\hline Holland & $78 \%$ & 4 & $22 \%$ & 4 \\
\hline Italy & $82 \%$ & 2 & $18 \%$ & 2 \\
\hline Switzerland & $65 \%$ & 8 & $35 \%$ & 8 \\
\hline
\end{tabular}


Table 4. Top European CEOs' priorities to go out of the crisis in a long-lasting way

\begin{tabular}{|c|c|c|c|c|c|c|c|c|}
\hline \multicolumn{9}{|c|}{ Rate the following in terms of priorities for your company to go out of the crisis in a long-lasting way } \\
\hline \% More important (*) & Austria & Belgium & Denmark & France & Germany & Holland & Italy & Switzerland \\
\hline Core competencies & $\underline{79 \%}$ & $69 \%$ & $65 \%$ & $57 \%$ & $64 \%$ & $58 \%$ & $66 \%$ & $62 \%$ \\
\hline Client / market orientation & $\underline{79 \%}$ & $\underline{76 \%}$ & $\underline{75 \%}$ & $\underline{76 \%}$ & $\underline{76 \%}$ & $\underline{78 \%}$ & $\underline{73 \%}$ & $\underline{81 \%}$ \\
\hline HR management & $37 \%$ & $38 \%$ & $38 \%$ & $54 \%$ & $27 \%$ & $49 \%$ & $52 \%$ & $34 \%$ \\
\hline Financial management & $42 \%$ & $35 \%$ & $36 \%$ & $32 \%$ & $28 \%$ & $26 \%$ & $41 \%$ & $27 \%$ \\
\hline
\end{tabular}

Note: $(*)$ the most important per country is underlined in bold.

Table 5. Top European CEOs' priorities in the client market orientation

\begin{tabular}{|c|c|c|c|c|c|c|c|c|}
\hline \multicolumn{9}{|c|}{ Rate the following in terms of priorities for your company to go out of the crisis in a long-lasting way } \\
\hline \% More important (*) & Austria & Belgium & Denmark & France & Germany & Holland & Italy & Switzerland \\
\hline Client / market orientation & $79 \%$ & $76 \%$ & $75 \%$ & $76 \%$ & $76 \%$ & $78 \%$ & $73 \%$ & $81 \%$ \\
\hline Improve quality of clients' portfolio & $37 \%$ & $28 \%$ & $28 \%$ & $24 \%$ & $31 \%$ & $46 \%$ & $36 \%$ & $27 \%$ \\
\hline Acquire new clients & $63 \%$ & $\underline{73 \%}$ & $\underline{68 \%}$ & $\underline{72 \%}$ & $\underline{77 \%}$ & $\underline{72 \%}$ & $\underline{61 \%}$ & $\underline{76 \%}$ \\
\hline Retain clients (loyalty) & $63 \%$ & $63 \%$ & $46 \%$ & $53 \%$ & $48 \%$ & $71 \%$ & $\overline{61 \%}$ & $52 \%$ \\
\hline Identify new expectations & $47 \%$ & $59 \%$ & $25 \%$ & $35 \%$ & $40 \%$ & $66 \%$ & $30 \%$ & $39 \%$ \\
\hline Improve clients' service & $\underline{68 \%}$ & $48 \%$ & $44 \%$ & $51 \%$ & $44 \%$ & $50 \%$ & $14 \%$ & $42 \%$ \\
\hline Open to new markets & $32 \%$ & $49 \%$ & $47 \%$ & $44 \%$ & $28 \%$ & $46 \%$ & $39 \%$ & $39 \%$ \\
\hline Internationalize the business & $16 \%$ & $20 \%$ & $12 \%$ & $19 \%$ & $19 \%$ & $13 \%$ & $14 \%$ & $15 \%$ \\
\hline Improve the ability to deliver & $32 \%$ & $31 \%$ & $33 \%$ & $43 \%$ & $37 \%$ & $38 \%$ & $38 \%$ & $32 \%$ \\
\hline Improve the negotiating skills & $11 \%$ & $15 \%$ & $22 \%$ & $16 \%$ & $11 \%$ & $21 \%$ & $5 \%$ & $13 \%$ \\
\hline Increase the orders' income & $5 \%$ & $18 \%$ & $22 \%$ & $25 \%$ & $20 \%$ & $13 \%$ & $14 \%$ & $16 \%$ \\
\hline Increase the quality of orders' portfolio & $21 \%$ & $17 \%$ & $15 \%$ & $9 \%$ & $14 \%$ & $27 \%$ & $14 \%$ & $9 \%$ \\
\hline
\end{tabular}

Note: $\left({ }^{*}\right)$ the most important per country is underlined in bold.

Table 6. Top European CEOs' priorities in the core competencies management

\begin{tabular}{|c|c|c|c|c|c|c|c|c|}
\hline \multicolumn{9}{|c|}{ Rate the following in terms of priorities for your company to go out of the crisis in a long-lasting way } \\
\hline \% More important (*) & Austria & Belgium & Denmark & France & Germany & Holland & Italy & Switzerland \\
\hline Core competencies & $79 \%$ & $69 \%$ & $65 \%$ & $57 \%$ & $64 \%$ & $58 \%$ & $66 \%$ & $62 \%$ \\
\hline Increase the innovation & $53 \%$ & $\underline{70 \%}$ & $56 \%$ & $65 \%$ & $\underline{52 \%}$ & $67 \%$ & $\underline{82 \%}$ & $56 \%$ \\
\hline Increase the investments & $16 \%$ & $30 \%$ & $25 \%$ & $15 \%$ & $18 \%$ & $21 \%$ & $38 \%$ & $17 \%$ \\
\hline Improve the quality of the offering & $32 \%$ & $44 \%$ & $33 \%$ & $46 \%$ & $28 \%$ & $46 \%$ & $45 \%$ & $40 \%$ \\
\hline Improve the quality of services & $\underline{63 \%}$ & $63 \%$ & $48 \%$ & $\underline{71 \%}$ & $44 \%$ & $59 \%$ & $45 \%$ & $\underline{57 \%}$ \\
\hline Improve the quality of the recruitment & $21 \%$ & $31 \%$ & $19 \%$ & $29 \%$ & $20 \%$ & $20 \%$ & $30 \%$ & $28 \%$ \\
\hline Improve the quality of the training & $21 \%$ & $32 \%$ & $28 \%$ & $26 \%$ & $19 \%$ & $40 \%$ & $30 \%$ & $23 \%$ \\
\hline Decrease the staff turnover rate & $5 \%$ & $8 \%$ & $7 \%$ & $4 \%$ & $11 \%$ & $13 \%$ & $7 \%$ & $11 \%$ \\
\hline Facilitate the organic growth & $47 \%$ & $34 \%$ & $\underline{60 \%}$ & $31 \%$ & $45 \%$ & $36 \%$ & $11 \%$ & $37 \%$ \\
\hline Facilitaite the external growth & $37 \%$ & $31 \%$ & $34 \%$ & $25 \%$ & $25 \%$ & $21 \%$ & $14 \%$ & $17 \%$ \\
\hline Invest in the human resources & $37 \%$ & $65 \%$ & $28 \%$ & $41 \%$ & $44 \%$ & $68 \%$ & $63 \%$ & $40 \%$ \\
\hline Invest in the technology & $21 \%$ & $14 \%$ & $9 \%$ & $12 \%$ & $17 \%$ & $28 \%$ & $18 \%$ & $12 \%$ \\
\hline
\end{tabular}

Note: $(*)$ the most important per country is underlined in bold. 
Table 7. Top European CEOs' priorities in the HR management

\begin{tabular}{|c|c|c|c|c|c|c|c|c|}
\hline \multicolumn{9}{|c|}{ Rate the following in terms of priorities for your company to go out of the crisis in a long-lasting way } \\
\hline \% More important (*) & Austria & Belgium & Denmark & France & Germany & Holland & Italy & Switzerland \\
\hline HR management & $37 \%$ & $38 \%$ & $38 \%$ & $54 \%$ & $27 \%$ & $49 \%$ & $52 \%$ & $34 \%$ \\
\hline Motivate the Executives & $11 \%$ & $37 \%$ & $33 \%$ & $40 \%$ & $15 \%$ & $28 \%$ & $34 \%$ & $24 \%$ \\
\hline Motivate the middle management & $32 \%$ & $54 \%$ & $47 \%$ & $40 \%$ & $41 \%$ & $46 \%$ & $52 \%$ & $40 \%$ \\
\hline Motivate the employees & $\underline{58 \%}$ & $\underline{59 \%}$ & $\underline{61 \%}$ & $\underline{57 \%}$ & $\underline{55 \%}$ & $\underline{\mathbf{5 1 \%}}$ & $\underline{77 \%}$ & $\underline{50 \%}$ \\
\hline Encourage the internal promotion & $11 \%$ & $25 \%$ & $5 \%$ & $19 \%$ & $8 \%$ & $\underline{51 \%}$ & $9 \%$ & $6 \%$ \\
\hline Revise the salary grids & $11 \%$ & $11 \%$ & $5 \%$ & $7 \%$ & $16 \%$ & $4 \%$ & $30 \%$ & $12 \%$ \\
\hline Improve the skills & $42 \%$ & $54 \%$ & $44 \%$ & $46 \%$ & $50 \%$ & $50 \%$ & $48 \%$ & $47 \%$ \\
\hline Manage the careers & $21 \%$ & $27 \%$ & $15 \%$ & $19 \%$ & $23 \%$ & $19 \%$ & $36 \%$ & $19 \%$ \\
\hline Internationalize the careers & $5 \%$ & $8 \%$ & $2 \%$ & $6 \%$ & $14 \%$ & $5 \%$ & $11 \%$ & $8 \%$ \\
\hline Facilitate the project management & $42 \%$ & $42 \%$ & $53 \%$ & $47 \%$ & $53 \%$ & $40 \%$ & $18 \%$ & $38 \%$ \\
\hline Facilitate the flexibility of schedules & $11 \%$ & $20 \%$ & $13 \%$ & $10 \%$ & $10 \%$ & $31 \%$ & $14 \%$ & $12 \%$ \\
\hline Improve the social climate & $11 \%$ & $18 \%$ & $16 \%$ & $19 \%$ & $16 \%$ & $21 \%$ & $48 \%$ & $15 \%$ \\
\hline Facilitate the collaborative work & $32 \%$ & $28 \%$ & $18 \%$ & $15 \%$ & $38 \%$ & $52 \%$ & $14 \%$ & $36 \%$ \\
\hline Improve the level of delegation & $26 \%$ & $24 \%$ & $28 \%$ & $34 \%$ & $24 \%$ & $22 \%$ & $36 \%$ & $21 \%$ \\
\hline
\end{tabular}

Note: $(*)$ the most important per country score is underlined in bold.

Table 8. Top European CEOs' priorities in the financial management

\begin{tabular}{|c|c|c|c|c|c|c|c|c|}
\hline \multicolumn{9}{|c|}{ Rate the following in terms of priorities for your company to go out of the crisis in a long-lasting way } \\
\hline \% More important (*) & Austria & Belgium & Denmark & France & Germany & Holland & Italy & Switzerland \\
\hline Financial management & $42 \%$ & $35 \%$ & $36 \%$ & $32 \%$ & $28 \%$ & $26 \%$ & $41 \%$ & $27 \%$ \\
\hline To control over the stock price & $0 \%$ & $4 \%$ & $7 \%$ & $3 \%$ & $6 \%$ & $1 \%$ & $5 \%$ & $3 \%$ \\
\hline To check the financial health of clients & $26 \%$ & $48 \%$ & $45 \%$ & $49 \%$ & $36 \%$ & $46 \%$ & $61 \%$ & $42 \%$ \\
\hline To check the financial health of suppliers & $21 \%$ & $10 \%$ & $15 \%$ & $18 \%$ & $13 \%$ & $7 \%$ & $14 \%$ & $12 \%$ \\
\hline To increase the net cash & $47 \%$ & $31 \%$ & $25 \%$ & $32 \%$ & $20 \%$ & $37 \%$ & $45 \%$ & $24 \%$ \\
\hline To decrease the level of debts & $32 \%$ & $23 \%$ & $28 \%$ & $24 \%$ & $9 \%$ & $13 \%$ & $41 \%$ & $12 \%$ \\
\hline To increase the dividend to shareholders & $11 \%$ & $14 \%$ & $2 \%$ & $4 \%$ & $3 \%$ & $23 \%$ & $5 \%$ & $4 \%$ \\
\hline To improve financial ratios & $11 \%$ & $8 \%$ & $12 \%$ & $6 \%$ & $13 \%$ & $29 \%$ & $7 \%$ & $5 \%$ \\
\hline To increase the profits & $\underline{68 \%}$ & $\underline{61 \%}$ & $\underline{73 \%}$ & $\underline{69 \%}$ & $\underline{60 \%}$ & $\underline{56 \%}$ & $\underline{77 \%}$ & $\underline{65 \%}$ \\
\hline To increase the cash flow & $53 \%$ & $51 \%$ & $38 \%$ & $29 \%$ & $31 \%$ & $54 \%$ & $32 \%$ & $37 \%$ \\
\hline To increase the working capital needs & $11 \%$ & $25 \%$ & $14 \%$ & $15 \%$ & $6 \%$ & $28 \%$ & $14 \%$ & $6 \%$ \\
\hline To increase the working capital & $11 \%$ & $17 \%$ & $31 \%$ & $13 \%$ & $8 \%$ & $13 \%$ & $11 \%$ & $6 \%$ \\
\hline
\end{tabular}

Note: $(*)$ the most important per country score is underlined in bold.

Table 9. Levels of priorities and levels of completion of action plans

\begin{tabular}{|c|c|c|c|c|c|c|c|c|}
\hline \multicolumn{9}{|c|}{ Average is $\mathbf{1 0 0}$ for both importance and completion level across priorities } \\
\hline & \multicolumn{2}{|c|}{ Client / market orientation } & \multicolumn{2}{|c|}{$\begin{array}{c}\text { Core Competencies } \\
\text { management }\end{array}$} & \multicolumn{2}{|c|}{$\begin{array}{c}\text { Financial } \\
\text { management }\end{array}$} & \multicolumn{2}{|c|}{$\begin{array}{c}\text { HR } \\
\text { management }\end{array}$} \\
\hline & $\begin{array}{c}\text { Index } \\
\text { importance }\end{array}$ & $\begin{array}{c}\text { Index } \\
\text { completion }\end{array}$ & $\begin{array}{c}\text { Index } \\
\text { importance }\end{array}$ & $\begin{array}{c}\text { Index } \\
\text { completion }\end{array}$ & $\begin{array}{c}\text { Index } \\
\text { importance }\end{array}$ & $\begin{array}{c}\text { Index } \\
\text { completion }\end{array}$ & $\begin{array}{c}\text { Index } \\
\text { importance }\end{array}$ & $\begin{array}{c}\text { Index } \\
\text { completion }\end{array}$ \\
\hline $\begin{array}{l}\text { Total } \\
\text { Europe }\end{array}$ & 117 & 110 & 107 & 100 & 79 & 118 & 97 & $\underline{72}$ \\
\hline
\end{tabular}

Note: $(*)$ underlined in bold, lowest completion rate. 
Table 10. Top European CEOs' ongoing action plans in the HR management

\begin{tabular}{|c|c|c|c|c|c|c|c|c|}
\hline \multicolumn{9}{|c|}{ Rate the following in terms of completed or ongoing action plans within your company } \\
\hline \% Completed + still running & Austria & Belgium & Denmark & France & Germany & Holland & Italy & Switzerland \\
\hline \multicolumn{9}{|l|}{ HR management } \\
\hline Motivate the Executives & $\underline{85 \%}$ & $42 \%$ & $64 \%$ & $52 \%$ & $40 \%$ & $61 \%$ & $42 \%$ & $45 \%$ \\
\hline Motivate the middle management & $50 \%$ & $45 \%$ & $60 \%$ & $52 \%$ & $48 \%$ & $69 \%$ & $62 \%$ & $44 \%$ \\
\hline Motivate the employees & $45 \%$ & $57 \%$ & $65 \%$ & $46 \%$ & $\underline{57 \%}$ & $70 \%$ & $53 \%$ & $47 \%$ \\
\hline Encourage the internal promotion & $50 \%$ & $72 \%$ & $25 \%$ & $31 \%$ & $47 \%$ & $\underline{82 \%}$ & $\underline{89 \%}$ & $53 \%$ \\
\hline Revise the salary grids & $50 \%$ & $38 \%$ & $50 \%$ & $20 \%$ & $19 \%$ & $50 \%$ & $53 \%$ & $36 \%$ \\
\hline Improve the skills & $38 \%$ & $53 \%$ & $65 \%$ & $42 \%$ & $44 \%$ & $59 \%$ & $89 \%$ & $57 \%$ \\
\hline Manage the careers & $25 \%$ & $58 \%$ & $38 \%$ & $31 \%$ & $33 \%$ & $33 \%$ & $50 \%$ & $49 \%$ \\
\hline Internationalize the careers & $35 \%$ & $33 \%$ & $25 \%$ & $20 \%$ & $32 \%$ & $33 \%$ & $50 \%$ & $50 \%$ \\
\hline Facilitate the project management & $38 \%$ & $\underline{77 \%}$ & $67 \%$ & $63 \%$ & $46 \%$ & $69 \%$ & $40 \%$ & $\underline{63 \%}$ \\
\hline Facilitate the flexibility of schedules & $10 \%$ & $43 \%$ & $73 \%$ & $\underline{71 \%}$ & $47 \%$ & $69 \%$ & $63 \%$ & $61 \%$ \\
\hline Improve the social climate & $50 \%$ & $54 \%$ & $71 \%$ & $54 \%$ & $32 \%$ & $71 \%$ & $52 \%$ & $39 \%$ \\
\hline Facilitate the collaborative work & $83 \%$ & $70 \%$ & $\underline{80 \%}$ & $30 \%$ & $40 \%$ & $66 \%$ & $38 \%$ & $51 \%$ \\
\hline Improve the level of delegation & $40 \%$ & $71 \%$ & $75 \%$ & $52 \%$ & $36 \%$ & $60 \%$ & $35 \%$ & $34 \%$ \\
\hline
\end{tabular}

Note: $(*)$ the most important per country score is underlined in bold. 